\title{
Did Neandertals and anatomically modern humans coexist in northern Italy during the late MIS 3?
}

\author{
Laura Longo $^{\mathrm{a}, *}$, Elisabetta Boaretto ${ }^{\mathrm{b}}$, David Caramelli ${ }^{\mathrm{c}}$, Paolo Giunti ${ }^{\mathrm{d}}$, Martina Lari ${ }^{\mathrm{c}}$, Lucio Milani ${ }^{\mathrm{c}}$, \\ Marcello A. Mannino ${ }^{\mathrm{e}}$, Benedetto Sala ${ }^{\mathrm{f}}$, Ursula Thun Hohenstein ${ }^{\mathrm{f}}$, Silvana Condemi ${ }^{\mathrm{g}}$ \\ a Università degli Studi di Siena, Dipartimento di Scienze Ambientali “G. Sarfatti”, U.R. Ecologia Preistorica, Via Tommaso Pendola 62, 53100 Siena, Italy \\ ${ }^{\mathrm{b}}$ Radiocarbon Dating and Cosmogenic Lab., Kimmel Center for Archaeological Science, Weizmann Institute of Science, 76100 Rehovot, Israel \\ ${ }^{\mathrm{c}}$ Università di Firenze, Dipartimento di Biologia Evoluzionistica, Laboratorio di Antropologia, Unità di Antropologia Molecolare/Paleogenetica Via del Proconsolo 12, \\ 50122 Firenze, Italy \\ ${ }^{\mathrm{d}}$ Istituto Italiano di Preistoria e Protostoria, Via S. Egidio 21, 50122 Firenze, Italy \\ e Department of Human Evolution, Max Planck Institute for Evolutionary Anthropology, Deutscher Platz 6, 04103 Leipzig, Germany \\ ${ }^{\mathrm{f}}$ Università di Ferrara, Dipartimento di Biologia ed Evoluzione, Sezione di Paleobiologia, Preistoria e Antropologia, Corso Ercole I d'Este 32, 44100 Ferrara, Italy \\ ${ }^{g}$ UMR 6578 CNRS-Université de la Méditerranée-EFS, Laboratoire d'Anthropologie bioculturelle, Faculté de Médecine - Secteur Nord, CS80011, Bd Pierre Dramard, \\ 13344 Marseille Cedex 15, France
}

\section{A R T I C L E I N F O}

\section{Article history:}

Available online 22 August 2011

\begin{abstract}
A B S T R A C T
The main processes invoked to explain the demise of Homo neanderthalensis are the effects of adverse climatic conditions in the northern hemisphere during Marine Isotope Stage 3 (MIS 3) and the outcome of the interaction with Anatomically Modern Humans (AMHs). Evidence for the co-existence of these two hominins, however, is elusive and, therefore, verifying the role which these processes might have played in the extirpation of Neandertals remains a topic of heated debate. A site which can contribute to throw light on the replacement of $H$. neanderthalensis by AMHs is Riparo Mezzena, a rockshelter in northern Italy, where late Mousterian lithic industries were found in association with human remains. This paper reviews the results of recent investigations on the lithic assemblages and human bones recovered during excavation campaigns which took place in 1957 and 1977. The study of the physical anthropology of the skeletal remains, in conjunction with palaeogenetic analyses on mitochondrial and nuclear DNA, have proven that the occupiers of Riparo Mezzena were Neandertals. The first radiocarbon date for the site, obtained on collagen extracted from a bovid from the lowermost part of the stratigraphic sequence (Layer III) and presented here $\left(34,540 \pm 655{ }^{14} \mathrm{C}\right.$ uncal BP), attests that Riparo Mezzena was occupied during the Middle-to-Upper Palaeolithic transition period. The anthropogenic deposits at the site actually accumulated when the nearby site of Grotta di Fumane was occupied by humans who produced Proto-Aurignacian lithic industries. This suggests that Neandertals and AMHs probably co-existed for a short period of time in northern Italy, possibly competing for resources within the confined territory of the Monti Lessini. These findings arising from new research on the collections of Riparo Mezzena have important implications not only for the study of the Middle-to-Upper Palaeolithic transition in Italy, but also for the understanding of the process through which AMHs replaced $H$. neanderthalensis.
\end{abstract}

(c) 2011 Elsevier Ltd and INQUA. All rights reserved.

\footnotetext{
* Corresponding author.

E-mail addresses: longo10@unisi.it, longoflint@gmail.com (L. Longo), elisabetta. boaretto@weizmann.ac.il (E. Boaretto), david.caramelli@unifi.it (D. Caramelli), tayacgiunti@hotmail.com (P. Giunti), martina.lari@unifi.it (M. Lari), milalucio@ yahoo.it (L. Milani), marcello_mannino@eva.mpg.de (M.A. Mannino), b.sala@unife. it (B. Sala), hhu@unife.it (U. Thun Hohenstein), silvana.condemi@univmed.fr (S. Condemi).
}

\section{Introduction}

In the last ten years or so the debate on the Middle-to-Upper Palaeolithic transition and on the causes of the extinction of Homo neanderthalensis $(\mathrm{Hn})$ has been fuelled not only by the acquisition of data through state of the art analytical techniques, such as AMS radiocarbon dating, palaeogenetic and isotopic analyses, but also through the re-evaluation of collections from past excavations and by the adoption of interpretative models on behavioural and subsistence adaptations (Schmitz et al., 2002; Hoffecker, 2009; Crevecoeur et al., 2010; Golovanova et al., 2010). 
AMS radiocarbon dating on sites associated with late Neandertals and early Homo sapiens (AMHs) indicates that the biological, cultural and behavioural shift which took place with the Middle-Upper Palaeolithic transition occurred between 40 and $28 \mathrm{ka}$ ${ }^{14} \mathrm{C}$ uncal BP (Smith et al., 1999; Ovchinnikov et al., 2000; Wild et al., 2005; Higham et al., 2006a; Semal et al., 2009; Jöris et al., 2011).

Mitochondrial palaeogenetic analysis (Caramelli et al., 2003, 2008; Serre et al., 2004; Currat and Escoffier, 2004; Briggs et al., 2009) has highlighted the differences between $\mathrm{Hn}$ and AMHs. The draft of the Neandertal genome (Green et al., 2010), however, supports the hypothesis that a certain admixture between AMHs and Hn probably occurred, given that both Europeans and Australasians share 1\%-4\% of their nuclear DNA with Neandertals, although Africans do not. This implies that early AMHs interbred with Neandertals after modern humans left Africa, but before they spread into Eurasia and Australasia. However, even if this is most parsimonious explanation, another hypothesis could also explain the genetic data: the existence of an old substructure in Africa that persisted from the origin of Neandertals until the ancestors of non-Africans left Africa (Green et al., 2010). Three main models have been proposed to explain the replacement of late Middle Palaeolithic (LMP) technologies early by Upper Palaeolithic (EUP) ones: the "single-species" model (Bar-Yosef, 2002; BarYosef, 2006a; Gravina et al., 2005; Mellars, 2005, 2006a,b), the "multiple-species" model (McBrearty and Brooks, 2000; Harrold and Otte, 2001; d'Errico, 2003; d'Errico et al., 2003; Hensilwood and Marean, 2003; Zilhão, 2006; Anikovich et al., 2007) and the "Mosaic" model (Clark, 2002; Cabrera et al., 2006; Straus, 2007).

There is no general agreement within the scientific community regarding the dynamics of the biological $(\mathrm{Hn} / \mathrm{AMH})$ and cultural shifts (LMP/EUP). As a result of this, some authors have recently proposed that the two questions should be to some extent decoupled (Bernaldo de Quirós and Maíllo-Fernández, 2009).

In the light of the present state of knowledge, an important area for investigating the biological, behavioural and cultural shifts which took place with the Middle-to-Upper Palaeolithic transition is the territory of the Lessini Mountains (Monti Lessini). The reasons for this are that this area of northern Italy was occupied during the period in question and both $\mathrm{Hn}$ and AMHs left behind traces of their presence at numerous cave and rockshelter sites. The collections from the 1957 and 1977 excavations at Riparo Mezzena are potentially of great scientific interest, given that, as will be shown in the present paper, this is the only site in Italy, and one of the few in Europe, to have yielded human bone fossils which date to the Middle-to-Upper Palaeolithic transition period, producing frankly Mousterian techno-complexes. The following sections of this article will describe the site of Riparo Mezzena, review the preliminary results of recent anthropological and palaeogenetic studies on the human remains and of the studies of the lithic industries from this site. In addition, it presents the first radiometric date for the site, which, as will be discussed, has important implications for the debate on the transition from the Middle to the Upper Palaeolithic. This research has been undertaken within the remit of the 'Human Fossil from Verona area' project, along with other studies on collections from Riparo Mezzena, which include archaeozoological and isotopic analyses and which are all aimed at improving understanding of the process by which Neandertals were replaced by AMHs in the Italian Peninsula.

\section{Riparo Mezzena}

\subsection{Site}

Riparo Mezzena is a rockshelter at $250 \mathrm{~m}$ a.s.l., which opens onto the Vajo Gallina in the Lessini Mountains, reliefs to the north of the
Po plain and of the modern city of Verona (Fig. 1A and B). The shelter is small, around $60 \mathrm{~m}^{2}$ (Fig. 1C), and access to the site easy from the top of the Nummulites limestone formation in which it occurs. Riparo Mezzena is located in an area within which raw materials and water, necessary for human subsistence, would have been easily obtained. In addition, the rockshelter would have been strategically placed for observing seasonally migrating mammalian herbivores, following the 'natural paths' that characterize the morphology of the Lessini Mountains (Thun-Hohenstein et al., 2012).

\subsection{Stratigraphic sequence}

The deposit at Riparo Mezzena, excavated in 1957 by Zorzi and Pasa of the Museo di Storia Naturale di Verona, was 1.5-1.7 m thick and composed of three main lithological layers (Fig. 1D). The original interpretation of the stratigraphic sequence was confirmed by investigations arising from a test excavation carried out in 1977, under the aegis of the University of Ferrara, on a baulk left unexcavated in 1957. The 1977 excavation campaign included the application of a wide range of studies aimed at clarifying site formation processes and at reconstructing the palaeoecological changes, which occurred around the site during the accumulation of its deposit (Bartolomei et al., 1980). The stratigraphic sequence was subdivided into the following units, starting from the base and moving towards the top.

Layer III, about $70 \mathrm{~cm}$ thick, rests directly on top of the bedrock. It is composed of a sandy sediment characterized at the bottom by mid-sized pebbles, while towards the top of the layer the rocks tend to become more angular, which is evidence for thermoclastic weathering. These sedimentological features, along with data from pollen and faunal analyses, have been interpreted by the excavators as indicating a relatively humid and temperate continental climate in the Lessini Mountains during the deposition of this layer (Bartolomei et al., 1980). The pollen recovered within the deposits at Riparo Mezzena suggest the presence, within a short distance from the site, of deciduous woodlands (Carpinus, Juglans, Alnus, Betula) and open grasslands (Cattani, 1980), similar to those of the Mammoth Steppe or taiga-steppe, an ecosystem which during MIS3 was spread across the Po plain (Gallini and Sala, 2001). This varied environment was characterised by a great biodiversity, with red deer, roe deer and large bovids being the main herbivores, but with other mammalian taxa such as ibex and irish elk, as well as wild boar, also present in the site catchment (Thun-Hohenstein et al., 2012). The presence in Layer III of various hearths in succession, separated from one another by a few centimetres of sediment, suggests multiple episodes of occupation by Neandertals, who repeatedly used the shelter for subsistence activities, taking back to it lithic and faunal resources probably attained within the daily foraging radius.

Layer II is composed of a loessic sediment, in which at least three concretion levels have been identified; the thickness of this layer varies from 50 to $70 \mathrm{~cm}$. The pollen from this layer is consistent with an open grassland with scattered Pinus silvestris, Alnus and Betula (Cattani, 1980). Palaeoecological data suggest that among ungulates, red deer and roe deer, were still dominant opposite to cold environment species (elk, Irish elk, chamois and ibex) which are absent with the exception of marmot (ThunHohenstein et al., 2012) supporting for a quite temperate arid climate.

The presence of a few hearths suggests various episodes of human occupation. The Mousterian lithic assemblage is less abundant than in the layer below, probably due to the more sporadic presence of $\mathrm{Hn}$ in the rockshelter at this time. 


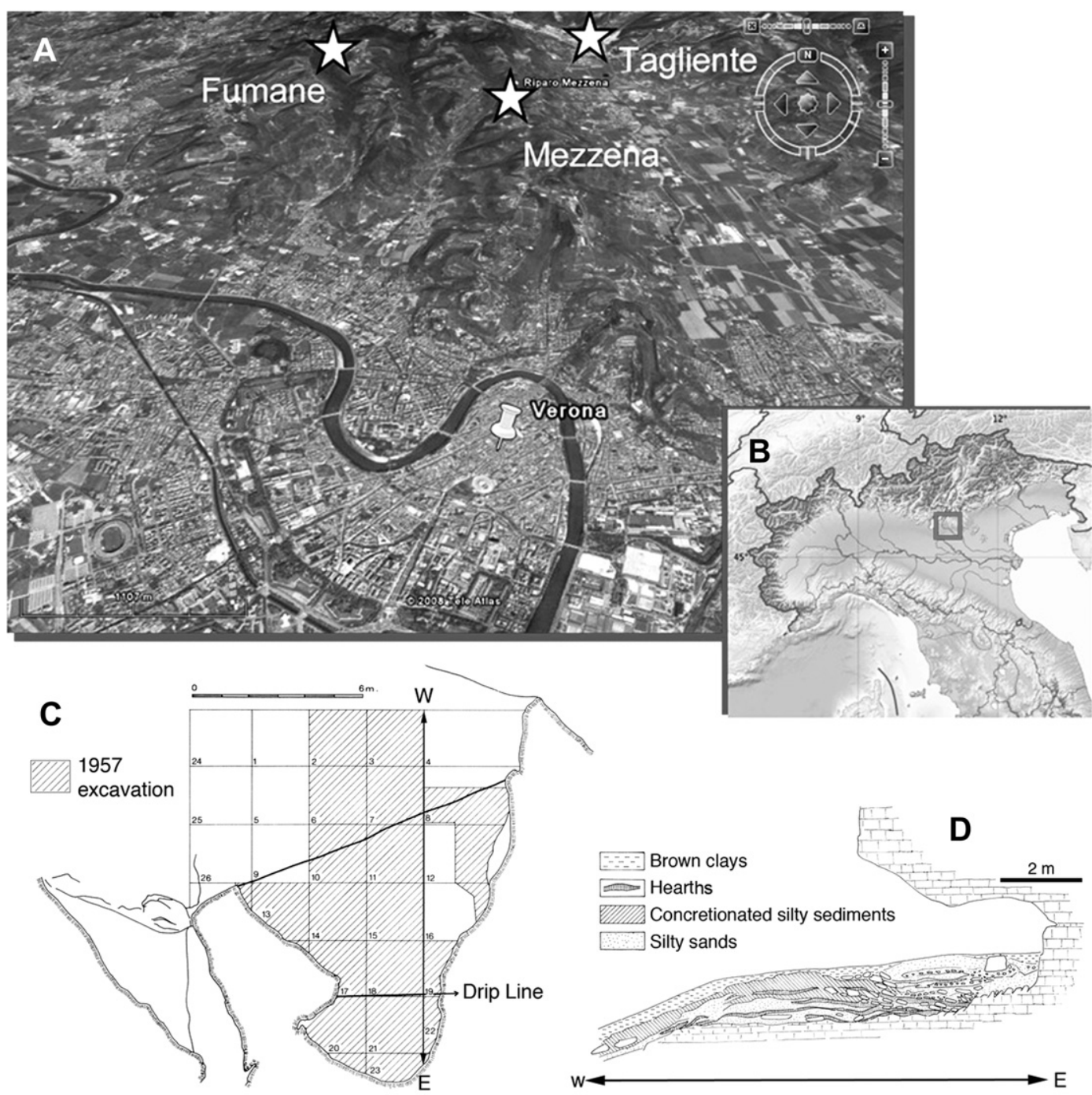

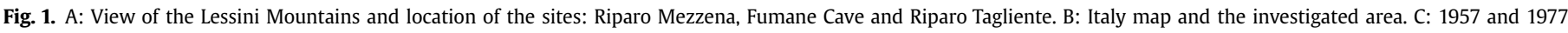
excavations. D: Lithotypes identified at Riparo Mezzena on the section E-W.

Layer I, the uppermost part of the surviving deposits, was divided into two sub-layers (Ia and Ib) during excavation. It is made up of reddish brown sediment which, in the light, assumes an earthy uniform dark brown colour. The maximum thickness of this layer was about $30 \mathrm{~cm}$.

This layer contained almost exclusively Mousterian lithics and faunal remains attributable to the closing stages of the Middle Palaeolithic. A few pottery fragments and bones of Holocene fauna have also been recovered in Layer I, suggesting that this part of the deposit was disturbed by the activities of Bronze age groups that visited the cave. However, given that this uppermost layer does not contain material culture or bones of later prehistoric age, it is likely that the undisturbed deposit was truncated in the mid-Holocene and only reworked in the Bronze Age. Layer I is of great interest because its lowermost portion (sub-layer Ib) contained fifteen human bone fragments which, as described in more detail below, are attributable to $\mathrm{Hn}$. It is not entirely clear whether these bones were primarily deposited during the initial accumulation of Layer I or whether they actually originate from the uppermost part of Layer II. On the basis of the sedimentological, palynological and palaeontological studies undertaken by Bartolomei et al. (1980) it can be concluded that the entire deposit at Riparo Mezzena accumulated during MIS 3 and is largely in situ.

\section{Morphology of the human remains}

The human fossils from sub-layer layer Ib include an incomplete jaw represented by the symphyseal region and a section of the mandibular corpus, eleven cranial fragments and three fragments of post-cranial elements.

The mandible (inv. no.: IGVR-203334 is incomplete and no teeth are preserved. As the result of a pathological condition, some of the teeth were lost ante mortem (Condemi et al., submitted for publication).

The two vertical branches and the right side of the mandibular corpus are broken, the symphyseal region is complete. On its left side, the body of the mandible is conserved up to the level of the second molar. The mandibular corpus is morphometrically similar to European Neandertals and, in particular, to Neandertal Circeo III from central Italy (Condemi, 2001; Giunti et al., 2008).

The cranial fragments are attributable to frontal, occipital and parietal bones, and might belong to a single individual, although it is not possible to refit them. The thickness of all the cranial fragments is remarkable and stands outside the range of variation of modern Europeans, while it is within the upper range of variation of Neandertals (Condemi, 2001; Giunti et al., 2008). The fragmentary state of the material allows only limited anatomical analyses, 
although some of these bones, such as the frontal and occipital fragments, bear diagnostic Neandertals traits. For example, a frontal bone fragment (inv. no.: IGVR 63017-5) is very flat, as is typical for $\mathrm{Hn}$ and, in particular, for the Neandertals of the Italian Peninsula (e.g. Saccopastore and Guattari). In view of their state of preservation and of their morphological traits, these fossils may have belonged to the same adult individual.

The taxonomic attribution of these bones to $\mathrm{Hn}$ has been confirmed by repeated palaeogenetic analyses, as reviewed below. A detailed study of the physical anthropology of these fragmentary fossils, as well as comparative analyses, are currently being completed.

\section{Palaeogenetic analyses}

Three human bone fragments labelled MLS 1 (parietal), MLS 2 (parietal) and MLS 3 (scapula), have been sampled for palaeogenetic analyses. Diagnostic fragments of mitochondrial DNA (mtDNA), ranging from nucleotide (nt) 16230 to nt 16262, have made it possible to attribute bone fragments, which are difficult to assess through morphological analysis, to $H$. neanderthalensis (Caramelli et al., 2006). In the case of the MLS 1 sample it was possible to obtain a fragment spanning to $16024 \mathrm{nt}$ to $16400 \mathrm{nt}$ of hypervariable 1 (HVR-1) of mitochondrial DNA sequence. This data allowed Caramelli et al. (2006) to demonstrate that the Neandertals of southern Europe had a high degree of genetic diversity compared to their conspecifics in northern regions of the continent.

The good perseveration and high level of endogenous DNA in the MLS 1 specimen has also enabled the recovery of nuclear DNA fragments: i) melanocortin 1 receptor gene $(m c 1 r)$ and ii) the gene of microcephalin (mcph1).

The $m c 1 r$ gene is responsible for skin and hair colour variation in humans and other vertebrates. Variants of $m c 1 r$ with reduced function are associated with pale skin color and red hair in humans. Lalueza-Fox et al. (2007) amplified and sequenced a fragment of the mc1rgene from MLS 1 and from a Neandertal specimen from El Sidrón Cave in Spain. Both specimens had a mutation that was not found in 3700 modern humans analyzed. Functional analyses performed on this variant showed a reduced $m c 1 r$ activity and the data suggested that inactive $m c 1 r$ variants evolved independently in both modern humans and Neandertals. The weakened activity of this variant suggests that Neandertals probably had pale skin and/or red hair.

The gene microcephalin or mcph1 is a critical regulator of brain size and likely plays an essential role in promoting the proliferation of neural progenitor cells during neurogenesis, supporting the possibility that it may have contributed to the phenotypic evolution of the human brain (Evans et al., 2005). The high frequency (around 0.70 worldwide) and relatively young age (between 14,000 and 62,000 years) of a derived group of haplotypes, haplogroup $D$, at the $m c p h 1$ locus has led to the hypothesis that haplogroup D originated in a human lineage that separated from modern humans $>1$ million years ago, evolved under strong positive selection and passed onto the human gene pool by an episode of admixture circa 37,000 years ago (Lari et al., 2010) The geographic distribution of haplogroup D, with marked differences between Africa and Eurasia, suggests that the archaic human form admixing with AMHs might have been Neandertal. By sequencing a fragment of the microcephalin locus of specimen MLS 1, it was possible to empirically demonstrate that this sample was homozygous for the ancestral, non-D, allele.

The mcph1 genotype of the MLS 1 specimen from Riparo Mezzena does not provide conclusive evidence on whether interbreeding took place in Europe between $\mathrm{Hn}$ and AMHs, but it shows that the speculations on a possible Neandertalian origin of what is now the most common mcph1 haplogroup are not supported by empirical evidence from ancient DNA.

\section{Lithic industries}

The tens of thousands artefacts unearthed within the deposits at Riparo Mezzena are undisputedly attributable to the La Ferrassie facies of the Mousterian cultural complex (Bartolomei et al., 1980). This is also the case of the lithic assemblage from Layer I, in spite of the fact that this uppermost part of the deposit was reworked in the Holocene by Bronze Age occupants. The main features of the lithic industries from Riparo Mezzena are described in the following paragraphs.

The raw materials used consist primarily of flints derived from the Mesozoic limestone formations of Maiolica, Scaglia Variegata, Scaglia Rossa and, in lower percentages, Eocene Limestone, all available within $5-15 \mathrm{~km}$ from the site. The stone material originates from sub-primary and secondary deposits. It is also available in the creeks at the bottom of the canyons cutting the Lessini Mountains along an $\mathrm{N}-\mathrm{S}$ axis, as it is observable from the base of the cortex deterioration, even on some technological categories (Longo and Giunti, 2010).

Flint was exploited through two production systems employing different blanks: the first one made use of natural unmodified lithic resources (blocks, nodules, slabs), while the second one exploited the dorsal or ventral surfaces of flakes (cores-on-flakes) originating from by-products of knapping or introduced directly into the site from outside.

The cores and predetermined blanks suggest the adoption of three operative production systems. The most frequently adopted one was guided by the Levallois predetermination concept (Boëda, 1994), while discoidal production was definitely subordinated. Some lithics in Layer II result from the application of the laminar volumetric concept to prismatic cores with one trimmed striking platform. Levallois cores are linked to the recurrent unidirectional method (Fig. 2, nos. 5, 7) and to its variants, recurrent centripetal (Fig. 2, nos. 1, 6) and preferential modalities (Giunti and Longo, 2008; Giunti and Longo, 2011).

Unidirectional modality (Fig. 2, nos. 2-4; 8-11) produces predetermined blanks with different functional characteristics, obtained with diverse strategies which ensure that the technical objectives are met. The reduction process, adopted after shaping with Levallois predetermination criteria, is based on obtaining successive series of predetermined blanks. Once the first Levallois series had been obtained, flaking may have continued through one of two strategies:

- the first one aimed at resharpening of convexities in order to obtain a new predetermined series with the same flaking axis as the previous ones, an operation which may have been performed until the final stage of the reduction process;

- the second one (limited option), instead, is based on changing the flaking axis of the new predetermined series, obtained by rotating the core by about $90^{\circ}$ or $180^{\circ}$. This operation should have been preceded by the production of a new trimmed striking platform and, sometimes, by a partial resharpening of the convexities.

The centripetal modality was adopted at the onset of the reduction sequence and differs between cores worked to produce predetermined blanks through centripetally (Fig. 3, nos. 1, 5-6) or chordally oriented removals.

Preferential modality displays different strategies for shaping through the Levallois criteria of predetermination, with the flaking surface being prepared by centripetal or unidirectional removals. Some cores may represent the transitional stage from recurrent modalities to preferential ones. A few lithics have a discoidal volumetric structure.

The laminar concept of the lithics present in the Layer II is characterized by a unidirectional operative scheme. The shaping of 


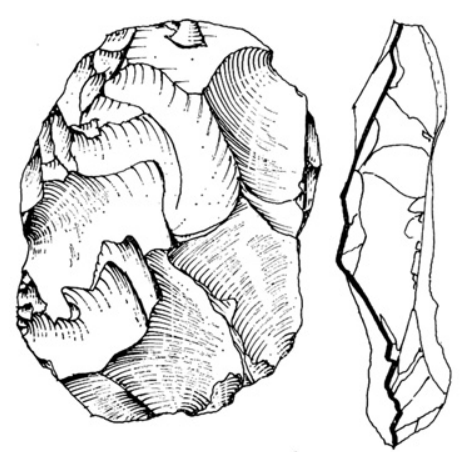

1
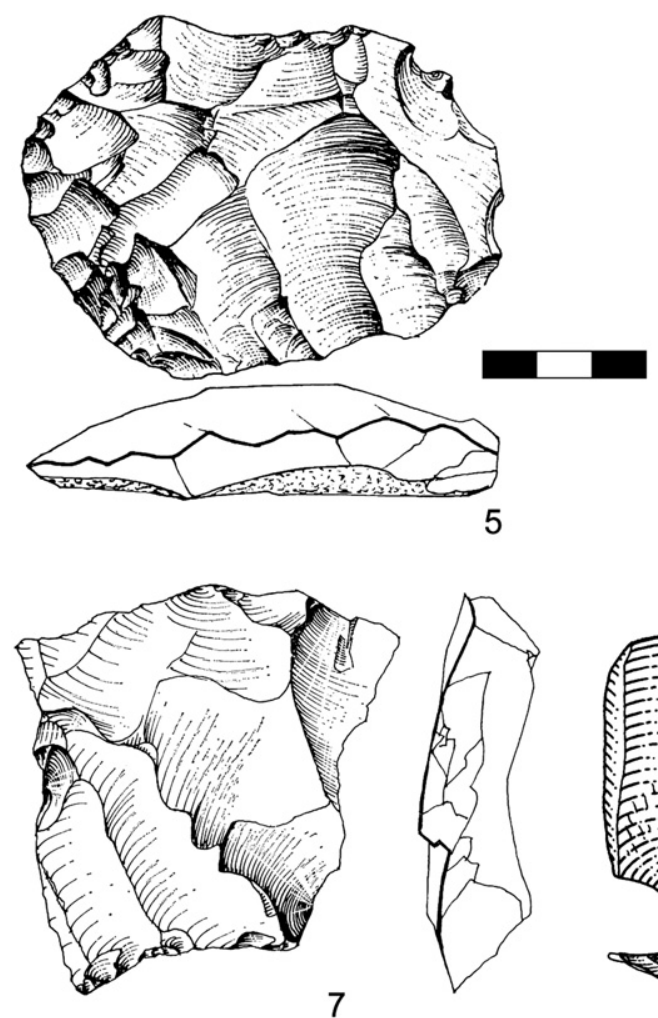

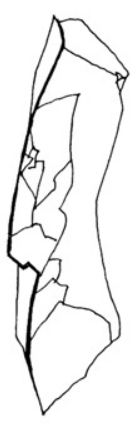

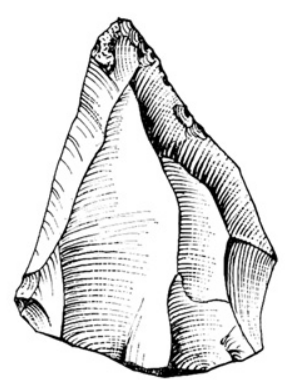
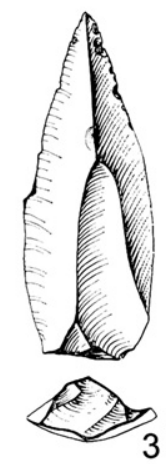

3

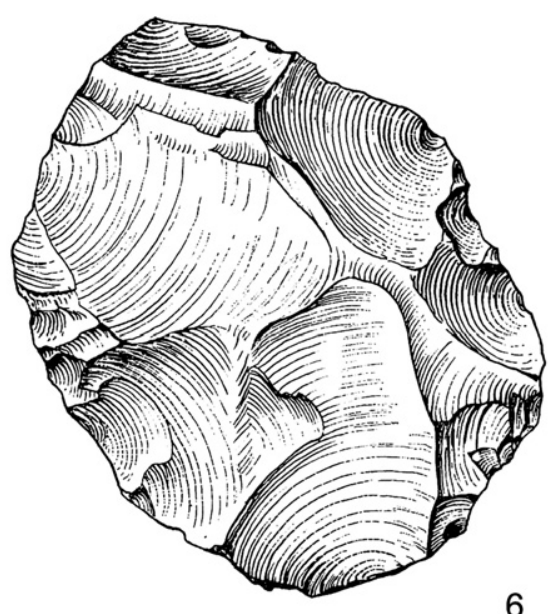

6
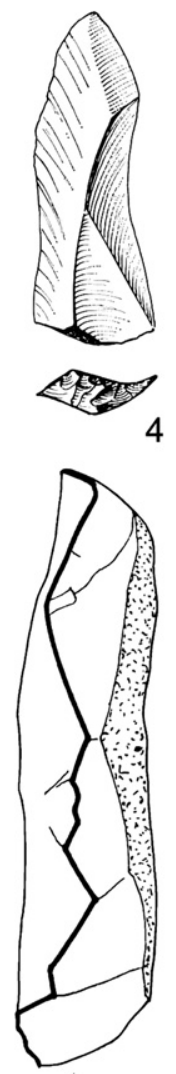
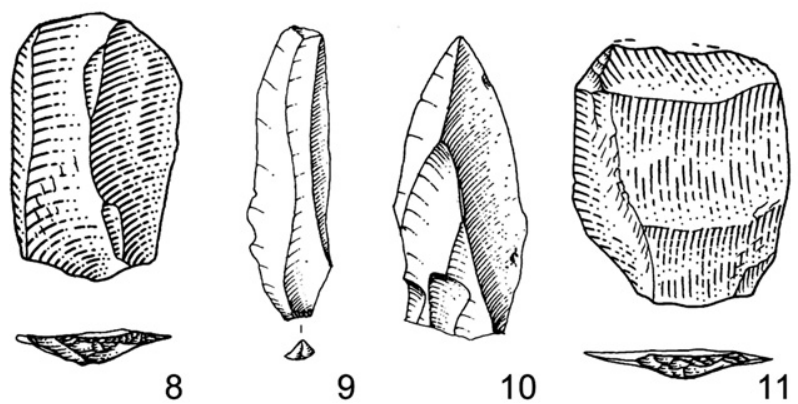

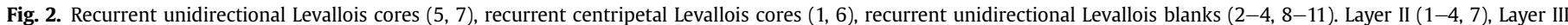
$(5-6,8-11)$.

the flaking surface was not achieved though the removal of a first crested blade.

The typological structure is characterized by the strong occurrence of the typical Mousterian composition (Bordes, 1961). Group II types are well represented (Fig. 3, nos. 2-4, 7-14), among which simple side scrapers are followed by Mousterian points, déjetés, transverse scrapers and by other categories.

Group III tools (Fig. 4, nos. 1-23) are rare and maintain the same frequency in the two layers, while Group IV tools slightly increase from bottom to top, with a consequent reduction in Mousterian group tools.

\section{AMS radiocarbon dating}

Three organic remains were selected for dating: two animal bones from Layer III and a parietal bone fragment from Layer Ib, which has been genetically-typed to $\mathrm{Hn}$. This paper reports the result of the dating on one of the two faunal samples from Layer III, specifically that obtained from the second phalanx of a bovid (inv. no: V10276). Collagen extraction on these samples included a superultrafiltration step (Higham et al., 2006b) and infrared spectroscopy to check the quality of the extract.

Fourier Transform Infrared Analysis (FTIR) indicated that the collagen extracted from the bovid bone phalanx was not contaminated by clay from the soil of deposition. The well-preserved bovid bone collagen was measured using Acceleration Mass Spectrometry (AMS). This sample (V10276, radiocarbon laboratory code RTT5578) was dated to $34,540 \pm 655{ }^{14} \mathrm{C}$ uncal BP (coll\% $=0.7 ; \%$ $\mathrm{C}=38.8 ; \delta^{13} \mathrm{C}=-22.8 \%$ ) (Table 1 ). Collagen yield, \%C and carbon isotope ratios $\left(\delta^{13} \mathrm{C}\right)$ are compatible with those of well-preserved bone, confirming that the AMS radiocarbon date has been obtained on biogenic collagen, unaffected by contamination.

This date on a bone from the lowermost layer (III) indicates that the excavated deposits at Riparo Mezzena started accumulating in 

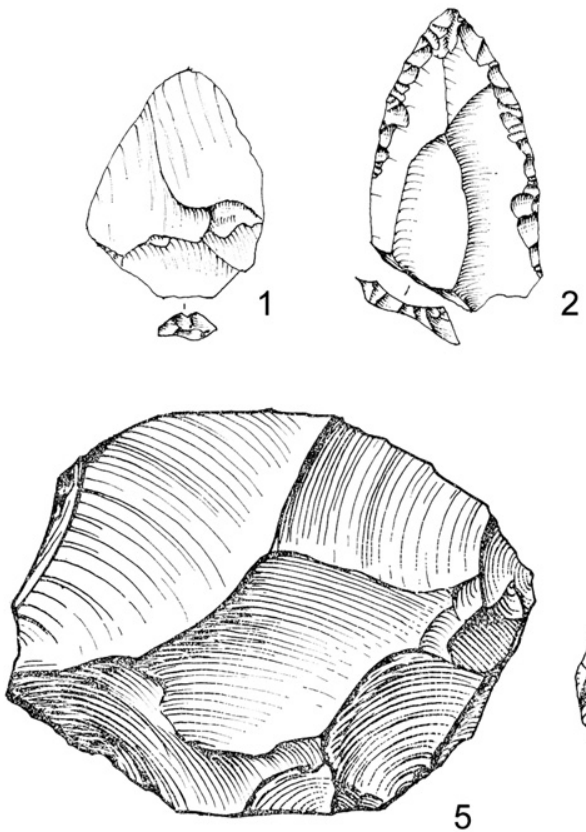

5
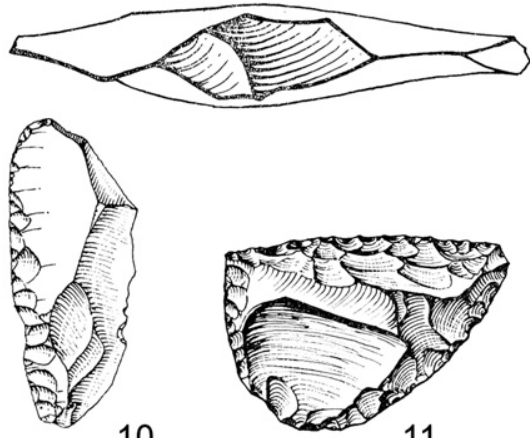

10

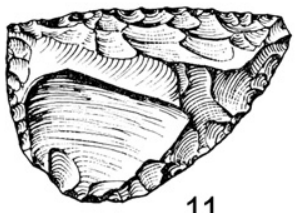

11
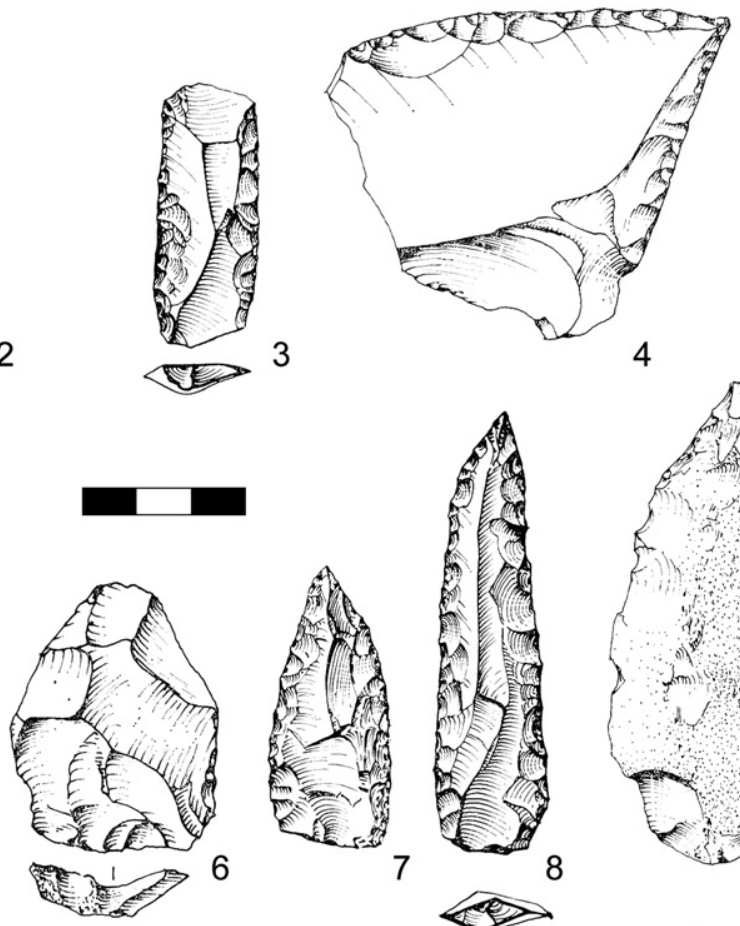

4
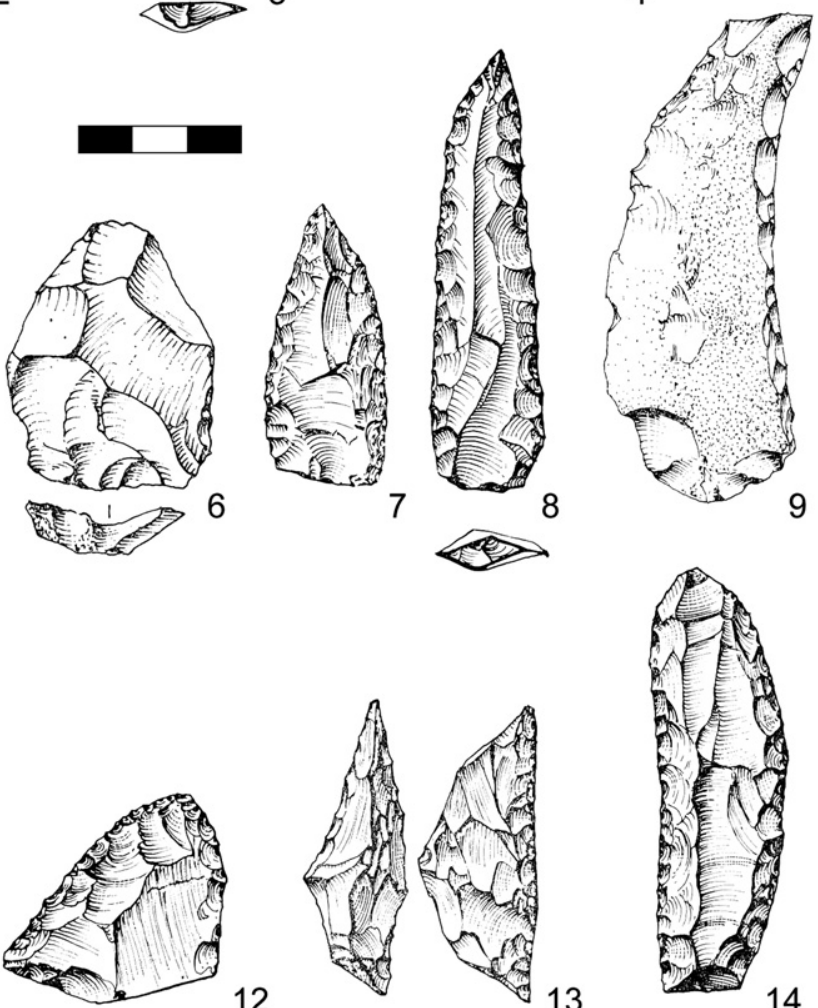

13

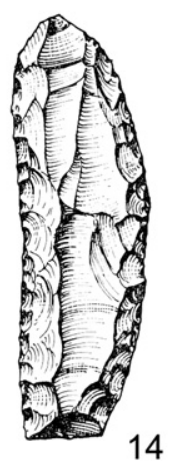

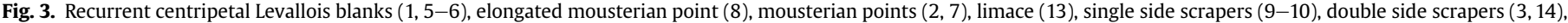
offset side scrapers $(4,11-12)$. Layer II $(3-5,7-9,13)$, Layer III $(1-2,6,10-12,14)$.

the closing stages of the Middle Palaeolithic and represents a terminus post quem for the uppermost layers and for the finds within them. Although other radiocarbon dates are needed to establish the temporal span of human occupation at Riparo Mezzena, the radiocarbon determination presented here allow some inferences on the chronology of the site and to link its stratigraphy to the climatic episodes which took place during late OIS3, which left their trace in the sediments at the rockshelter. Before discussing these issues, it should be noted that, as shown in Table 1, the calibrated age of the bovid bone from Layer III at Riparo Mezzena overlaps significantly with the range of ages for the ProtoAurignacian occupation at the nearby Grotta Fumane. This date from Riparo Mezzena proves that Neandertal occupation at this site was contemporary to Proto-Aurignacian occupation at Fumane and probably, therefore, to the presence of AMHs in the territory of the Lessini Mountains.

\section{Discussion}

The review of the data arising from the study of the Mousterian site of Riparo Mezzena and the first radiocarbon date obtained from it allow initiation of a discussion on the bio-cultural evolution which took place in Italy from the late Middle Palaeolithic to the early Upper Palaeolithic.

In Italy, as in the rest of Europe, a notable emphasis has been given recently to ${ }^{14} \mathrm{C}$ dating in establishing the chronological framework for the cultural and demographic dynamics which took place during this key transitional period for human evolution in Eurasia. Some of the numerical dates obtained on organic remains from sites with transitional deposits have been questioned along with the archaeological reconstructions originating from them (Giaccio et al., 2008; Higham et al., 2009).

A significant turning point, however, for the understanding of the chronology of the Middle Palaeolithic to Upper Palaeolithic transition in Italy has been achieved through the chrono-stratigraphic study of Campanian Ignimbrite $(\mathrm{CI})$, tephra deposits produced by the volcanic eruptions of the Phlegrean Fields, one of which dated in radiocarbon terms to $34.8-34.7 \mathrm{ka}{ }^{14} \mathrm{C} \mathrm{BP}$ (Anikovich et al., 2007; Hoffecker et al., 2008; Jöris et al., 2011).

$\mathrm{CI}$ only occurs in anthropogenic deposits in the southern regions of the Italian Peninsula, such as the open air site at Serino, the cave site of Grotta di Castelcivita on the Tyrrhenian side and the cave sites of Grotta di Uluzzo, Grotta Bernardini and Grotta del Cavallo on the Adriatic side (Giaccio et al., 2006, 2008). At all these sites the tephra seals stratigraphic sequences which from bottom to top 

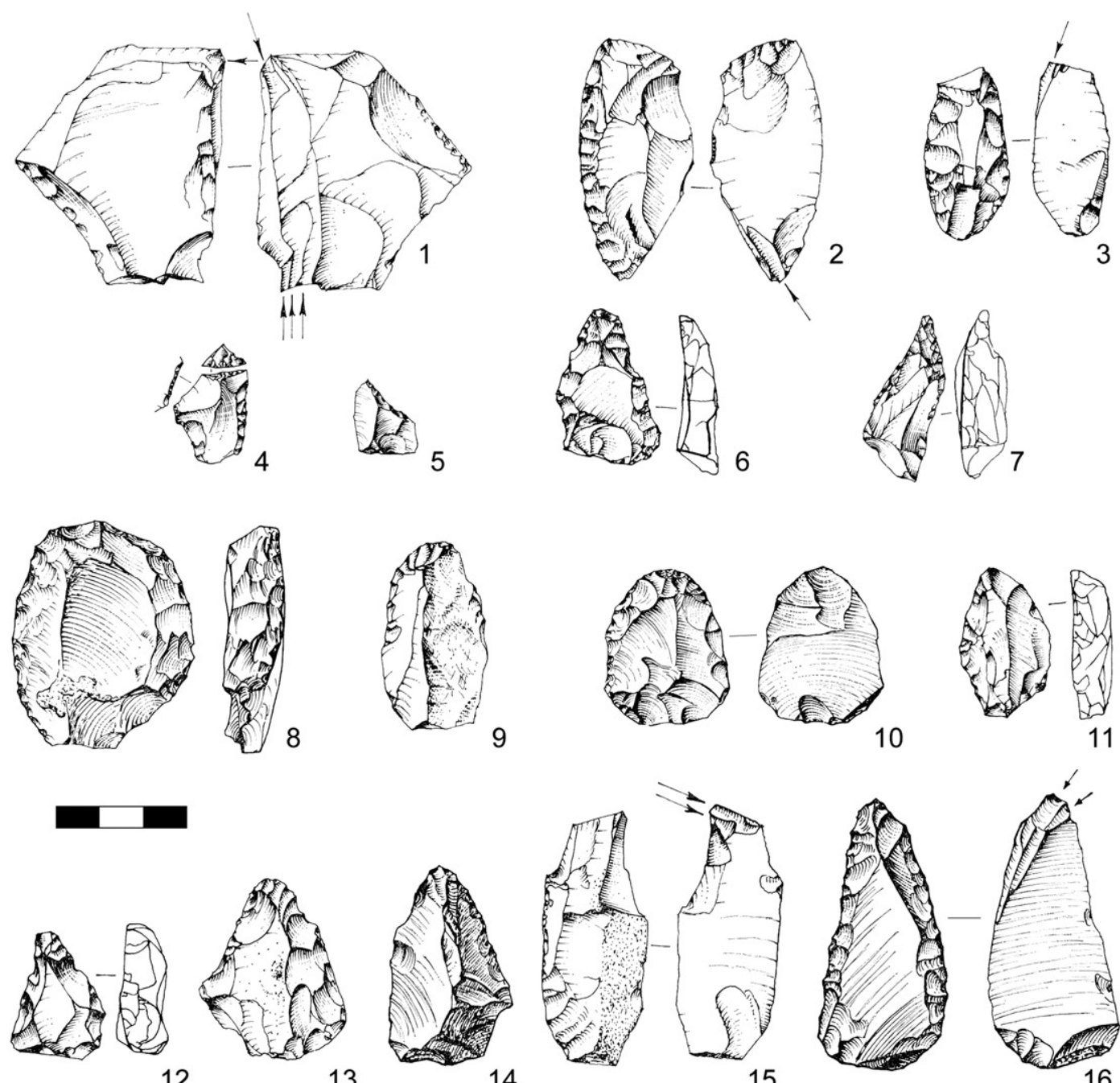

15
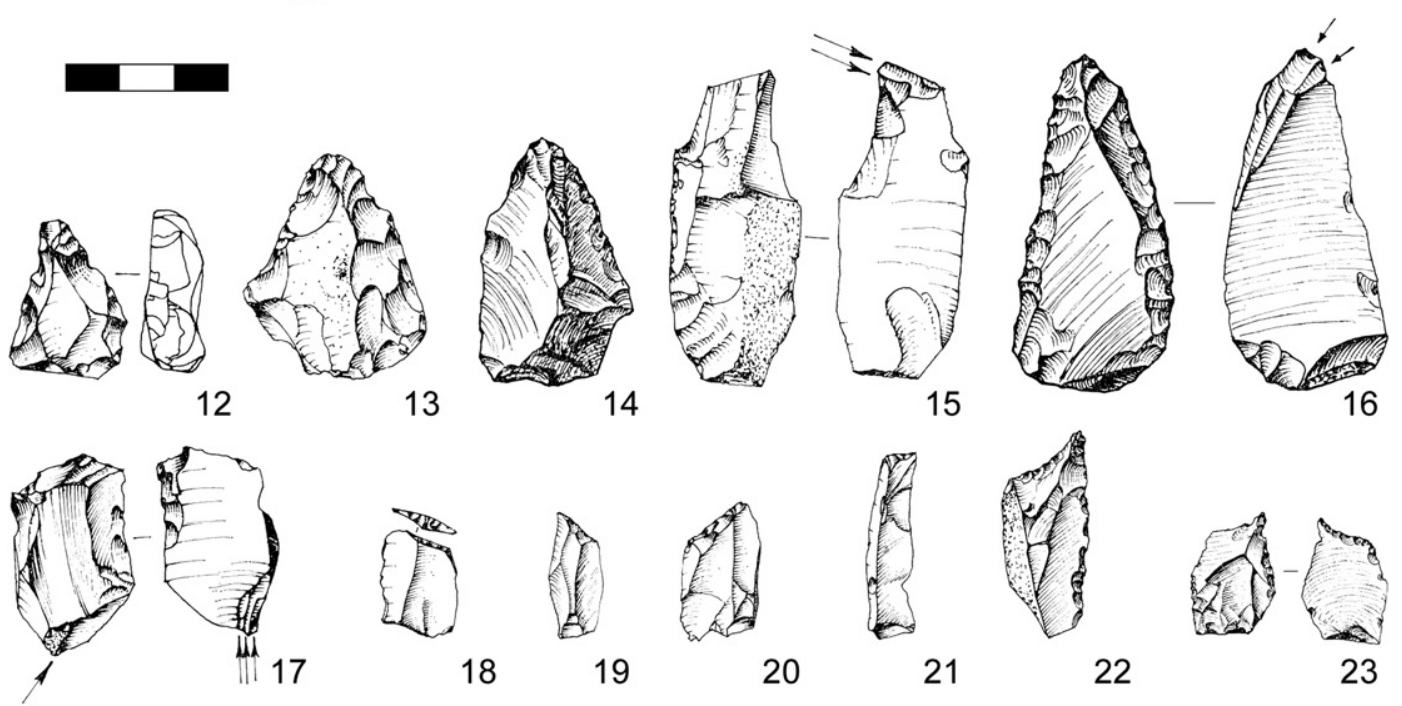

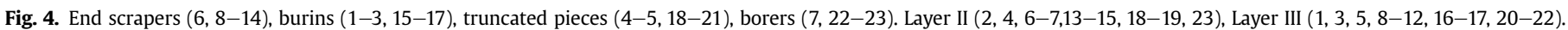

include Mousterian, Uluzzian and Proto-Aurignacian deposits, thereby indicating that the technological transition from Middle to Upper Palaeolithic industries probably had occurred by the time of the volcanic eruptions of the Phlegrean Fields. CI tephras, therefore, represent a terminus ante quem for the transition which probably started around the Greenland Interstadial 11 (GI 11) and ended around Heinrich Event 4 (HE 4), which coincided with the Phlegrean eruptions (Giaccio et al., 2008; Golovanova et al., 2010). The fact that one of the CI tephra has been precisely dated (De Vivo et al., 2001) and that it, therefore, appears as a reliable chronostratigraphic marker has brought into question the validity of some of the ${ }^{14} \mathrm{C}$ dates available for the transitional period, such as for example those from the Uluzzian deposits at Grotta di Castelcivita, which seemingly post-date the tephra (Gambassini, 1997).

The scenario of the Middle-to-Upper Palaeolithic transition in central and northern Italy remains unclear, not only because the ash fall from the Phlegrean eruption did not extend to this part of the Italian Peninsula and, therefore, the $\mathrm{CI}$ tephra is not present at sites in this area, but also because of the scarcity of radiocarbon dates for this period. The largest set of ${ }^{14} \mathrm{C}$ dates from a Middle-toUpper Palaeolithic transition site is that available for Grotta di Fumane, which has been the object of numerous dating projects (Higham et al., 2009). The most recent and reliable dates for charcoal samples from this site, obtained by using the acid-baseoxidation/stepped combustion (ABOx-SC) method, attest that, as in the case of the southern Italian sites, the Proto-Aurignacian layer pre-dates the eruption of the Phlegrean Fields. In other words, based on the evidence from Grotta di Fumane alone, Higham et al. (2009) suggested that in northern Italy the replacement of Hn by AMHs had taken place by around $35 \mathrm{ka}{ }^{14} \mathrm{C}$ uncal BP.

Setting aside for the moment issues of chronology, one of the main problems in studying the demise of Neandertals in Italy is linked to the attribution of lithic industries to their makers. Three lithic techno-complexes dating to the Middle-to-Upper Palaeolithic 
Table 1

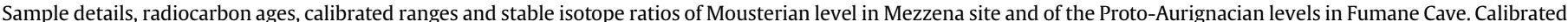

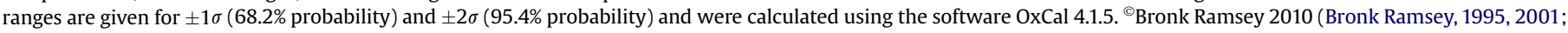
Higham et al., 2009) based on the calibration data in Reimer et al. (2009).

\begin{tabular}{|c|c|c|c|c|c|c|c|c|}
\hline \multirow[t]{2}{*}{ Site } & \multirow[t]{2}{*}{ Culture } & \multirow[t]{2}{*}{ Context } & \multirow[t]{2}{*}{ Lab. Numb. } & \multirow{2}{*}{$\begin{array}{l}\text { Sample } \\
\text { Method }\end{array}$} & \multirow[t]{2}{*}{${ }^{14}$ Cage BP } & \multicolumn{2}{|c|}{ Calibrated age BP } & \multirow{2}{*}{$\begin{array}{l}\delta^{13} \mathrm{C} \\
\% \text { PDB }\end{array}$} \\
\hline & & & & & & $\pm 1 \sigma$ range & $\pm 2 \sigma$ range & \\
\hline Mezzena & Mousterian & Lyr III & RTT 5578 & $\begin{array}{l}\text { Bone } \\
\text { AMS }\end{array}$ & $34,540 \pm 655$ & $40,380-38,840$ & $41,270-38,040$ & -22.8 \\
\hline Fumane Cave & Proto-Aurignacian & Lyr A2, sq. 97d & OxA-17569 & $\begin{array}{l}\text { Charcoal } \\
\text { AMS } \\
\text { ABOx-SC }\end{array}$ & $35,640 \pm 220$ & $41,170-40,620$ & $41,400-40,310$ & -22.5 \\
\hline Fumane Cave & Proto-Aurignacian & Lyr A2, struc. 18 & OxA-19584 & $\begin{array}{l}\text { Charcoal } \\
\text { AMS } \\
\text { ABOx-SC }\end{array}$ & $35,850 \pm 310$ & $41,400-40,750$ & $41,670-40,370$ & -23.8 \\
\hline Fumane Cave & Proto-Aurignacian & Lyr A2, struc. 16/lev. B & OxA-19414 & $\begin{array}{l}\text { Charcoal } \\
\text { AMS } \\
\text { ABOx-SC }\end{array}$ & $34,180 \pm 270$ & $39,440-38,720$ & $40,090-38,560$ & -24.7 \\
\hline Fumane Cave & Proto-Aurignacian & Lyr A2, struc. 17 & OxA-19412 & $\begin{array}{l}\text { Charcoal } \\
\text { AMS } \\
\text { ABOx-SC }\end{array}$ & $34,940 \pm 280$ & $40,520-39,540$ & $40,900-39,100$ & -24.2 \\
\hline Fumane Cave & Proto-Aurignacian & Lyr A2, sq. $107 \mathrm{i}$ & OxA-17570 & $\begin{array}{l}\text { Charcoal } \\
\text { AMS } \\
\text { ABOx-SC }\end{array}$ & $35,180 \pm 220$ & $40,850-40,080$ & $41,050-39,500$ & -21.7 \\
\hline
\end{tabular}

transition period were present in the Italian Peninsula: Mousterian, Uluzzian and Proto-Aurignacian (Palma di Cesnola, 1993; Kuhn and Bietti, 2000; Ronchitelli et al., 2009), the first two being attributed to indigenous Neandertals, while the latter to incoming AMHs. The Uluzzian, one of the so-called transitional industries, has been attributed to Hn because at Grotta del Cavallo it was found in association with teeth attributed to this hominin species (Palma di Cesnola and Messeri, 1967), although it should be noted that this taxonomic identification has been cast into doubt based, as it is, on four extremely weathered teeth (Churchill and Smith, 2000). The attribution of the Proto-Aurignacian to AMHs, on the other hand, has not been corroborated by the recovery of human remains at any of the sites where this techno-complex is attested. These three industries are not evenly distributed across the Italian Peninsula, because while the Mousterian and Proto-Aurignacian have been found at sites throughout Italy, the Uluzzian is distributed in central-southern Italy (Palma di Cesnola, 1993). Given the uncertainties which have been raised by numerous scholars (Kuhn and Bietti, 2000; Riel-Salvatore, 2009; Riel-Salvatore and Negrino, 2009) on the attribution to the Uluzzian of the industries from levels A4 and A3 at Grotta di Fumane (Bartolomei et al., 1992; Peresani, 2008), it can be stated that this techno-complex, according to Palma di Cesnola (1993) and Riel-Salvatore (2009), started developing before the arrival of AMHs in central and southern Italy, which occurred around $34-32$ ka ${ }^{14} \mathrm{C}$ uncal BP (Ronchitelli et al., 2009).

The radiocarbon date on the bovid bone from the base of the sequence at Riparo Mezzena, presented in this paper, is important (i) since it attests the presence of Late Mousterian Neandertals in the Italian, and not only in the Iberian (Delson and Harvati, 2006; Finlayson et al., 2006), peninsula and (ii) because, if supported by further dating, it has fundamental implications for the understanding of the Middle-to-Upper Palaeolithic transition in Italy. In fact, this date testifies that genetically-typed Neandertals, makers of Mousterian industries, were present in the territory of the Lessini Mountains till at least some time after $34 \mathrm{ka}{ }^{14} \mathrm{C}$ uncal BP, by when the makers of Proto-Aurignacian industries, probably AMHs, had been occupying Grotta di Fumane for a millennium (Higham et al., 2009).

This implies that indigenous groups of Hn probably came into contact with AMHs, thereby, pending new radiocarbon dates on bones from Riparo Mezzena, it can be postulated that in northern Italy the duration of this co-existence was not prolonged and probably ended around HE 4 . This hypothesis is supported by the fact that the interaction between the two hominin species in the Lessini Mountains did not result in acculturation or in the acquisition by Neandertals from AMHs of any of the traits supposedly associated with behavioural modernity (e.g. Mellars, 2005).

The evidence for the cultural separation of these two closelyrelated hominins in northern Italy is matched by ancient mitochondrial DNA data, which are compatible with a genetic discontinuity between $\mathrm{Hn}$ and AMHs (Caramelli et al., 2006). In fact, palaeogenetic data from the Riparo Mezzena specimens testify that Italian Neandertals had highly divergent mtDNA sequences compared to other Neandertals and they were separated from AMHs by several fixed mtDNA differences (Caramelli et al., 2006). This combined with nuclear DNA data (Lalueza-Fox et al., 2007; Lari et al., 2010) suggests that it is important to obtain further palaeogenetic data from the Mezzena fossils, in order to confirm or refute the admixture hypothesis in this part of Europe.

The radiocarbon date on the bovid from Riparo Mezzena may also have important implications for the interpretation of Uluzzian techno-complexes in Italy. The identification of the Uluzzian industry at Grotta di Fumane before the appearance of the ProtoAurignacian, which as mentioned above, has been taken with skepticism on techno-typological grounds (Kuhn and Bietti, 2000; Riel-Salvatore, 2009; Riel-Salvatore and Negrino, 2009), is now also cast into doubt by the new dating evidence from Riparo Mezzena. In fact, it seems unlikely (i) that Neandertal groups makers of different techno-complexes were present in the Lessini Mountains in the closing stages of the Middle Palaeolithic and (ii) that Neandertal groups supposedly producing Uluzzian industries (a) did not leave traces at other sites in northern Italy (including Riparo Mezzena) and (b) disappeared before their conspecifics who were still producing Mousterian industries.

The radiocarbon date from Riparo Mezzena might also have implications for the debate on the makers of the Uluzzian technocomplexes. The Neandertals that occupied Riparo Mezzena do not appear to have changed their technology significantly, neither before nor during the brief period of contact with AMHs. It can, therefore, be concluded that at least in NE Italy the transition between the Middle and the Upper Palaeolithic was marked by a discontinuity in biological, cultural and technological terms. If a similar scenario occurred throughout the Italian Peninsula, with the contact period being extremely brief, then it could even be postulated that the technological and behavioural modernity 
attested by Uluzzian industries and ornaments in southern Italy should be attributed to groups of AMHs, who might have migrated down from the Balkan Peninsula through the trans-Adriatic corridor during GI 11, taking with them an early Upper Palaeolithic techno-complex (Bar-Yosef, 2006a, b), similar to that from Klisoura I in Greece (Koumouzelis et al., 2001), a site from which human remains have not been recovered. This scenario would exclude the hypotheses put forward by Palma di Cesnola (1993, 2004) and Riel-Salvatore (2009), who suggested that the Uluzzian resulted from independent local evolution and in its latter stages from the acculturation of Neandertals by AMHs (Palma di Cesnola, 1993).

\section{Conclusions}

Recent studies aimed at clarifying the chronology of the Middle-to-Upper Palaeolithic transition in the Italian Peninsula (Giaccio et al., 2008; Higham et al., 2009) have demonstrated that the replacement of $\mathrm{Hn}$ by AMHs took place over a period of two to three millennia and that this event was probably over by the time of the volcanic eruption of the Phlegrean Fields, which roughly corresponds to HE 4. The sites on which these chrono-stratigraphic reconstructions are based lack skeletal remains of Homo, or at best were found to contain a few remains which are difficult to identify to species (i.e. Grotta del Cavallo; Palma di Cesnola and Messeri, 1967). Hypotheses on the disappearance of Neandertals and of their replacement by AMHs have, therefore, been based on the presence or absence of lithic industries tentatively attributable to either of these hominins. The fact that at the time of the ProtoAurignacian occupation at Grotta di Fumane, Hn was present in the nearby site of Riparo Mezzena and had still a frankly Mousterian industry throws new light on the transition from the Middle-to-Upper Palaeolithic shift in Italy, suggesting that these two hominins probably co-existed for a short period of time and that the co-existence resulted in bio-cultural discontinuity.

These observations, which are at present the only ones for Italy based on a dated site containing genetically-typed fossils undisputedly associated to a well defined lithic industry (i.e. the Mousterian), also have implications for the understanding of who made the Uluzzian. On the basis of the evidence from Riparo Mezzena, the Uluzzian was an industry limited to the central-southern Italian Peninsula and that it might have been associated to AMHs incoming from the Balkans through the trans-Adriatic corridor. This hypothesis is supported not only by the late persistence of Neandertals with Mousterian techno-complexes in northern Italy, but also by the stratigraphic sequences of the main deposits dating to the Middle-to-Upper Palaeolithic transition, which attest a cultural discontinuity between the Mousterian levels and the Uluzzian and Proto-Aurignacian levels above them (Pitti et al., 1976; Gambassini, 1997; Benini et al., 1998).

In conclusion, the currently available data are compatible with two possible explanations for the $\mathrm{Hn} / \mathrm{AMHs}$ shift in Italy: (i) Neandertals were absorbed in the AMH population through interbreeding or, more simply, (ii) the former were rapidly replaced by the latter, leaving very few traces. The short duration of the coexistence and the bio-cultural discontinuity attested by the data arising from the study of the Riparo Mezzena fossils suggest that the second hypothesis is the most parsimonious for the Italian Peninsula. On the whole, data from across Eurasia, also appear to support the idea that co-existence between Neandertals and AMHs was short-lived (Pinhasi et al., 2011) and that the replacement of the former by the latter hominin was a rapid process in most areas, with the possible exception of Iberia (Zilhão, 2006).

A more general consensus on the bio-cultural shift that took place in Eurasia during the Middle-to-Upper Palaeolithic transition might only be reached when a more conspicuous number of chronologically and culturally well-contextualized human remains of morphologically and genetically-typed specimens will be available. This is a necessary step, as much of the debate on the transition (e.g. Clark, 2002; d'Errico, 2003; Mellars, 2005; Bar-Yosef, 2006b; Zilhão, 2006; Straus, 2007) derives from uncertainties in the attribution of the transitional techno-complexes to their makers (Bailey et al., 2009), be it the Chatelperronian (Bar-Yosef and Bordes, 2010), the Uluzzian (Churchill and Smith, 2000), the Lincombian-Ranisian-Jerzmanowician (Semal et al., 2009) or others. The evidence presented in this paper, along with that which is arising from current work on the collections from Riparo Mezzena, is, therefore, crucially important for pondering on what was a very common, if not the most frequent, outcome of the co-existence of Neandertals of Late Mousterian culture and AMHs across Eurasia: the disappearance of the former leaving behind no tangible trace, apart from possibly a minor contribution to the genetic makeup of the latter.

\section{Author contributions}

L.L., P.G designed the manuscript and interpreted the data. E.B. analyzed samples and performed collagen ${ }^{14} \mathrm{C}$ AMS radiocarbon dating; S.C. analyzed the Neandertal human remains; D.C., L. M. and M. L. performed the paleoDNA analyses on the Neandertal collagen; U. T. and B.S. studied the faunal assemblage; L.L. and P.G. analyzed the lithic assemblage. L.L., P.G., D.C. and M.A.M. wrote the paper. All the authors discussed and commented on the manuscript.

\section{Acknowledgments}

We are thankful to J. Riel Salvatore (Boulder, Colorado Museum) Tom Higham (Oxford University) and L. Rook (Università di Firenze) for their critical reviews of the former versions of the manuscript. The "Human fossils of the Verona area" project is designed and coordinated since 2005 by Laura Longo.

\section{References}

Anikovich, M.V., Sinitsyn, A.A., Hoffecker, J.F., Holliday, V.T., Popov, V.V., Lisitsyn, S.N., Forman, S.L., Levkovskaya, G.M., Pospelova, G.A., Kuz'mina, I.E., Burova, N.D., Goldberg, P., Macphail, R.I., Giaccio, B., Praslov, N.D., 2007. Early Upper Paleolithic in eastern Europe and implications for the dispersal of modern humans. Science 315, 223-226.

Bailey, S.E., Weaver, T.D., Hublin, J.J., 2009. Who made the Aurignacian and other early Upper Palaeolithic industries. Journal of Human Evolution 57, 11-26.

Bar-Yosef, O., 2002. The Upper Paleolithic revolution. Annual Review of Anthropology 31, 363-393.

Bar-Yosef, O., 2006a. Defining the Aurignacian. In: Bar-Yosef, O., Zilhão, J. (Eds.) Towards a Definition of the Aurignacian. Trabalhos de Arqueologia, vol. 45. Artes Graficas, pp. 11-18.

Bar-Yosef, O., 2006b. Cro-Magnon and Neanderthals: a different interpretation. In: Conard, N.J. (Ed.), When Neanderthals and Modern Humans Met. Verlag, Tübingen, pp. 467-482.

Bar-Yosef, O., Bordes, J.-G., 2010. Who were the makers of the Châtelperronian culture? Journal of Human Evolution 59, 586-593.

Bartolomei, G., Cattani, L., Cremaschi, M., Pasa, A., Peretto, C., Sartorelli, A., 1980. Il Riparo Mezzena (Stratigrafia del deposito, sedimenti, pollini, faune, industrie). In: Memorie del Museo Civico di Storia Naturale di Verona, vol. 2 Sezione Scienze dell'Uomo.

Bartolomei, G., Broglio, A., Cassoli, P.F., Castelletti, L., Cattani, L., Cremaschi, M., Giacobini, G., Malerba, G., Maspero, A., Peresani, M., Sartorelli, A., Tagliacozzo, A., 1992. La Grotte de Fumane. Un site aurignacian au pied des Alpes. Preistoria Alpina 28, 131-179.

Benini, A., Boscato, P., Gambassini, P., 1998. Grotta della Cala (Salerno): industrie litiche e faune uluzziane e aurignaziane. Rivista di Scienze Preistoriche 48, 37-95.

Bernaldo de Quirós, F., Maíllo-Fernández, J.-M., 2009. The transitional Aurignacian and the Middle-Upper Palaeolithic transition model in Cantabrian Iberia. In: Camps, M., Chauhan, P. (Eds.), Sourcebook of Paleolithic Transition. Springer Science, pp. 341-359.

Boëda, É, 1994. Le Concept Levallois: variabilité des méthodes. In: Monographies du C.R.A., vol. 9. CNRS Éditions, Paris. 
Bordes, F., 1961. Typologie du Paléolithique ancient et moyen. In: Pubblications de l'Institut de Préhistoire de l'Universitè de Bordeaux, vol. 1 Bordeaux.

Briggs, A.W., Good, J.M., Green, R.E., Krause, J., Maricic, T., Stenzel, U., Lalueza-Fox, C. Rudan, P., Brajkovic, D., Kucan, Z., Gusic, I., Schmitz, R., Doronichev, V.B. Golovanova, L.V., de la Rasilla, M., Fortea, J., Rosas, A., Pääbo, S., 2009. Targeted retrieval and analysis of five Neanderthal mtDNA genomes. Science 5938, 318-321.

Bronk Ramsey, C., 1995. Radiocarbon calibration and analysis of stratigraphy: the OxCal program. Radiocarbon 37 (2), 425-430.

Bronk Ramsey, C., 2001. Development of the radiocarbon calibration program OxCal. Radiocarbon 43 (2A), 355-363.

Cabrera, V., Maíllo Fernandez, J.M., Pike-Tay, A., Garralda Benajes, M.D., Bernaldo de Quiros, F., 2006. A Cantabrian perspective on late Neandertals. In: Conard, N.J.(Ed.), When Neanderthals and Modern Humans met. Verlag, Tübingen, pp. 441-465.

Caramelli, D., Lalueza-Fox, C., Vernesi, C., Lari, M., Casoli, A., Mallegni, F., Chiarelli, B. Dupanloup, I., Bertranpetit, J., Barbujani, G., Bertorelle, G., 2003. Evidence for a genetic discontinuity between Neanderthals and 24,000 year-old anatomically modern Europeans. Proceedings of the National Academy of Sciences of the United States of America 100 (11), 6593-6597.

Caramelli, D., Lalueza-Fox, C., Condemi, S., Longo, L., Milani, L., Manfredini, A., de Saint Pierre, M., Adoni, F., Lari, M., Giunti, P., Ricci, S., Casoli, A., Calafell, F., Mallegni, F., Bertranpetit, J., Stanyon, R., Bertorelle, G., Barbujani, G., 2006. A highly divergent mtDNA sequence in a Neandertal individual from Italy. Current Biology 16 (16), 630-632.

Caramelli, D., Milani, L., Vai, S., Modi, A., Pecchioli, E., Girardi, M., Pilli, E., Lari, M. Lippi, B., Ronchitelli, A., Mallegni, F., Casoli, A., Bertorelle, G., Barbujani, G., 2008. A 28,000 years old Cro-Magnon mtDNA sequence differs from all potentially contaminating modern sequences. PLoS One 3 (7), e2700.

Cattani, L., 1980. Analisi pollinica del testimone residuo. In: Bartolomei, G. Cattani, L., Cremaschi, M., Pasa, A., Peretto, C., Sartorelli, A. (Eds.), Il Riparo Mezzena (Stratigrafia del deposito, sedimenti, pollini, faune, industrie). Memorie del Museo Civico di Storia Naturale di Verona, vol. 2, Sez. Scienze dell'uomo, pp. 11-12.

Churchill, S.E., Smith, F.H., 2000. Makers of the early Aurignacian of Europe. Yearbook of Physical Anthropology 43, 61-115.

Clark, G., 2002. Observations on paradigmatic bias in the French and American Paleolithic archaeology. In: Straus, L. (Ed.), The Role of American Archaeologist in the Study of the European Upper Paleolithic. British Archaeological Reports, International Series, vol. 1048, pp. 19-26.

Condemi, S., 2001. Les Néanderthaliens de la Chaise. In: Documents préhistoire, vol 15. Éditions du Comité des Travaux Historique et Scientifiques (CTHS), Paris.

Condemi, S., Tardivo, D., Foti, B., Ricci, S., Giunti, P., Longo, L., Dental pathology reveals Neandertal diet. Palevol, submitted for publication.

Crevecoeur, I., Bayle, P., Rougier, H., Maureille, B., Higham, T., Van der Plicht, J., De Clerck, N., Semal, P., 2010. The spy VI child: a newly discovered Neandertal infant. Journal of Human Evolution 59, 641-666.

Currat, M., Excoffier, L., 2004. Modern humans did not admix with Neanderthals during their range expansion into Europe. PLoS Biology 2, 2264-2274.

d'Errico, F., 2003. The invisible frontier: a multiple species model for the origin of behavioural modernity. Evolutionary Anthropology 12, 188-202.

d'Errico, F., Henshilwood, C., Lawson, G., Vanharen, M., Tillier, A.-M., Soressi, M. Bresson, F., Maureille, B., Nowell, A., Lakarra, J., Balckwell, L., Julien, M., 2003. Archaeological evidence for the emergence of language, symbolism, and music - an alternative multidisciplinary perspective. Journal of World Prehistory 17 $1-70$.

Delson, E., Harvati, K., 2006. Return of the last Neanderthal. Nature 443 (19), $762-763$

De Vivo, B., Rolandi, G., Gans, P.B., Calvert, A., Bohrson, W.A., Spera, FJ., Belkin, H.E. 2001. New constraints on the pyroclastic eruptive history of the Campanian volcanic plain (Italy). Mineralogy and Petrology 73, 47-65.

Evans, P.D., Gilbert, S.L., Mekel-Bobrov, N., Vallender, E.J., Anderson, J.R., VaezAzizi, L.M., Tishkoff, S.A., Hudson, R.R, Lahn, B. T, 2005. Microcephalin, a gene regulating brain size, continues to evolve adaptively in humans. Science 309 $1717-1720$

Finlayson, C., Pacheco, F.G., Rodríguez-Vidal, J., Fa, D.A., Gutierrez López, J.M., Santiago Pérez, A., Finlayson, G., Allue, E., Baena Preysler, J., Cáceres, I., Carrión, J.S Fernández Jalvo, Y., Gleed-Owen, C.P., Jimenez Espejo, F.J., López, P., López Sáez, J.A., Riquelme Cantal, J.A., Sánchez Marco, A., Guzman, F.G., Brown, K. Fuentes, N., Valarino, C.A., Villalpando, A., Stringer, C.B., Martinez Ruiz, F., Sakamoto, T., 2006. Late survival of Neanderthals at the southernmost extreme of Europe. Nature 443, 850-853.

Gallini, V., Sala, B., 2001. Settepolesini di Bondeno (Ferrara - Eastern Po Valley): the first example of mammoth steppe in Italy. In: Cavaretta, G., Gioia, P., Mussi, M. Palombo, M.R. (Eds.), The World of Elephas. Proceedings of the 1st International Congress, pp. 272-275.

Gambassini, P., 1997. Il Paleolitico di Castelcivita: Culture e Ambiente. Electa, Napoli.

Giaccio, B., Hajdas, I., Peresani, M., Fedele, F.G., Isaia, R., 2006. The Campanian Ignimbrite tephra and its relevance for the timing of the Middle to Upper Paleolithic shift. In: Conard, N.J. (Ed.), When Neanderthals and Modern Humans Met. Verlag, Tübingen, pp. 343-375.

Giaccio, B., Isaia, R., Fedele, F.G., Di Canzio, E., Hoffecker, J.F., Ronchitelli, A., Sinitsyn, A.A., Anikovich, M.A., Lisitsyn, S.N., Popov, V.V., 2008. The Campanian Ignimbrite and Codola tephra layers: two temporal/stratigraphic markers for the Early Upper Palaeolithic in southern Italy and eastern Europe. Journal of Volcanology and Geothermal Research 177, 208-226.
Giunti, P., Caramelli, D., Condemi, S., Longo, L., 2008. Il sito musteriano di Riparo Mezzena presso Avesa (Verona, Italia). Aggiornamenti metodologici e nuovi dati paleoantropologici, paleogenetici e paleocomportamentali. In: Bollettino del Museo Civico di Verona, vol. 32, pp. 39-53.

Giunti, P., Longo, L., 2008. Prime considerazioni sulla variabilità del sistema tecnico Levallois dello strato III di Riparo Mezzena (Monti Lessini, Italia settentrionale). Rivista di Scienze Preistoriche LVIII, 5-28.

Giunti, P., Longo, L., 2011. Production system of the mousterian lithic industry of layer 3 from Riparo Mezzena (Verona, northern Italy). In: Longo, L. (Ed.), Human Evolution Special Issue, 131-144.

Golovanova, L.V., Doronichev, V.B., Cleghorn, N.E., Koulkova, M.A., Sapelko, T.V., Shackley, M.S., 2010. Significance of Ecological factors in the Middle to Upper Paleolithic transition. Current Anthropology 51 (5), 655-691.

Gravina, B., Mellars, P., Ramsey, C., 2005. Radiocarbon dating of interstratified Neandertal and early modern human occupations at the Chatelperronian typesite. Nature $438,51-56$

Green, R.E., Krause, J., Briggs, A.W., Maricic, T., Stenzel, U., Kircher, M., Patterson, N., Li, H., Zhai, W., Fritz, M.H., Hansen, N.F., Durand, E.Y., Malaspinas, A.S., Jensen, J.D., Marques-Bonet, T., Alkan, C., Prüfer, K., Meyer, M., Burbano, H.A., Good, J.M. Schultz, R., Aximu-Petri, A., Butthof, A., Höber, B., Höffner, B., Siegemund, M., Weihmann, A., Nusbaum, C., Lander, E.S., Russ, C., Novod, N., Affourtit, J., Egholm, M., Verna, C., Rudan, P., Brajkovic, D., Kucan, Z., Gusic, I., Doronichev, V.B., Golovanova, L.V., Lalueza-Fox, C., de la Rasilla, M., Fortea, J., Rosas, A., Schmitz, R.W., Johnson, P.L., Eichler, E.E., Falush, D., Birney, E., Mullikin, J.C., Slatkin, M., Nielsen, R., Kelso, J., Lachmann, M., Reich, D., Pääbo, S., 2010. A draft sequence of the Neandertal genome. Science 328, 710-722.

Harrold, F., Otte, M., 2001. Time, space, and cultural process in the European Middle-Upper Paleolithic transition. In: Hays, M., Thacker, P. (Eds.), Questioning the Answers: Re-Solving Fundamental Problems of the Early Upper Paleolithic. British Archaeological Reports, International Series, vol. 1005, pp. 3-11.

Hensilwood, C.S., Marean, C.W., 2003. The origin of modern human behavior: critique of the models and their test implications. Current Anthropology 44, 627-651.

Higham, T., Bronk Ramsey, C., Karavanic, I., Smith, F.H., Trinkaus, E., 2006a. Revised direct radiocarbon dating of the Vindija G1 Upper Palaeolithic Neandertals. Proceedings of the National Academy of Sciences of the United States of America 103, 553-557.

Higham, T., Jacobi, R.M., Bronk Ramsay, C., 2006b. AMS radiocarbon dating of ancient bone using ultrafiltration. Radiocarbon 48, 179-195.

Higham, T., Brock, F., Peresani, M., Broglio, A., Wood, R., Douka, K., 2009. Problems with radiocarbon dating the Middle to Upper Palaeolithic transition in Italy. Quaternary Science Reviews 28, 1257-1267.

Hoffecker, J.F., 2009. The spread of modern humans in Europe. Proceedings of the National Academy of Sciences of the United States of America 106 (38), 16040-16045.

Hoffecker, J.F., Holliday, V., Anikovich, M.V., Sinitsyn, A.A., Popov, V.V., Lisitsyn, S.N., Levkovskaya, G.M., Pospelova, G.A., Forman, S.L., Giaccio, B., 2008. From the Bay of Naples to the River Don: the Campanian Ignimbrite eruption and the Middle to Upper Paleolithic transition in eastern Europe. Journal of Human Evolution $55,858-870$.

Jöris, O., Street, M., Terberger, T., Weninger, B., 2011. Radiocarbon dating the Middle to Upper Palaeolithic transition: the demise of the Last Neanderthals and the first appearance of anatomically modern humans in Europe. In: Condemi, S., Weniger, G.-C. (Eds.), Continuity and Discontinuity in the Peopling of Europe: One Hundred Fifty Years of Neanderthal Study. Vertebrate Paleobiology and Paleoanthropology, vol. 239. Springer Science, pp. 239-298.

Koumouzelis, M., Ginter, B., Kozłowski, J.K., Pawlikowski, M., Bar-Yosef, O., Albert, R.M., Litynska-Zajac, M., Stworzewicz, E., Wojtal, P., Lipecki, G., Tomek, T., Bochenski, Z.M., Pazdur, A., 2001. The Early Upper Palaeolithic in Greece: the excavations in Klisoura Cave. Journal of Archaeological Science 28, 515-539.

Kuhn, S.L., Bietti, A., 2000. The Late Middle and Early Upper Paleolithic in Italy. In: Bar-Yosef, O., Pilbeam, D. (Eds.), The Geography of Neandertals and Modern Humans in Europe and the Greater Mediterranean. Peabody Museum Bulletin, pp. $49-76$.

Lalueza-Fox, C., Rompler, H., Caramelli, D., Staubert, C., Catalano, G., Hughes, D. Rohland, N., Pilli, E., Longo, L., Condemi, S., de la Rasilla, M., Fortea, J., Rosas, A., Stoneking, M., Schoneberg, T., Bertranpetit, J., Hofreiter, M., 2007. A melanocortin 1 receptor allele suggests varying pigmentation among Neanderthals. Science 318, 1453-1455.

Lari, M., Rizzi, E., Milani, L., Corti, G., Balsamo, C., Vai, S., Catalano, G., Pilli, E., Longo, L., Condemi, S., Giunti, P., Hänni, C., De Bellis, G., Orlando, L., Barbujani, G., Caramelli, D., 2010. The microcephalin ancestral allele in a Neanderthal individual. PLoS One 5 (5), e10648.

Longo, L., Giunti, P., 2010. Settlement dynamics and raw material exploitation during Middle Palaeolithic in the Lessini Mountains (Verona, Veneto, Italy). In: Burdukiewicz, J.M., Wisniewski, A. (Eds.), Middle Palaeolithic Human Activity and Paleoecology: New Discoveries and Ideas. Acta Universitatis Wratislaviensis, Studia Archeologiczne, vol. 42, pp. 387-410.

McBrearty, S., Brooks, A.S., 2000. The revolution that wasn't: a new interpretation of the origin of modern human behavior. Journal of Human Evolution 39, 453-563.

Mellars, P., 2005. The impossible coincidence: a single-species model for the origins of modern human behavior in Europe. Evolutionary Anthropology 14, 12-27.

Mellars, P., 2006a. Archeology and the dispersal of modern humans in Europe: Deconstructing the 'Aurignacian'. Evolutionary Anthropology 15, 167-182. 
112

L. Longo et al. / Quaternary International 259 (2012) 102-112

Mellars, P., 2006b. Why did modern human populations disperse from Africa ca. 60,000 year ago? A new model. Proceedings of the National Academy of Sciences of the United States of America 103, 9381-9386.

Ovchinnikov, I.V., Götherström, A., Romanova, G.P., Kharitonov, V.M., Lidén, K., Goodwin, W., 2000. Molecular analysis of Neandertal DNA from the northern Caucasus. Nature 404, 490-493.

Palma di Cesnola, A., 1993. Il Paleolitico Superiore in Italia: Introduzione allo Studio. Garlatti e Razzai Editori, Firenze.

Palma di Cesnola, A., 2004. Rapports Entre l'Aurignacien et l' Uluzzien en Italie. In: Le Paléolithique Supérieur/The Upper Palaeolithic, Section 6. British Archaeological Reports, International Series, vol. 1240, pp. 7-12.

Palma di Cesnola, A., Messeri, P., 1967. Quatre dents humaines paléolithiques trouvées dans des cavernes de l'Italie méridionale. L'Anthropologie 71 (3-4), 249-262.

Peresani, M., 2008. A new cultural frontier for the Last Neanderthals: the Uluzzian in northern Italy. Current Anthropology 49 (4), 725-731.

Pinhasi, R., Higham, T., Golovanova, L.V., Doronichev, V.B., 2011. Revised age of late Neanderthal occupation and the end of the Middle Paleolithic in the northern Caucasus. Proceedings of the National Academy of Sciences of the United States of America 108 (21), 8611-8616.

Pitti, C., Sorrentino, C., Tozzi, C., 1976. L'industria di tipo Paleolitico superiore arcaico della Grotta La Fabbrica (Grosseto). Nota preliminare. In: Atti della Società Toscana di Scienze Naturali, Memorie, Serie A, vol. 83, pp. 174-201.

Reimer, P.J., Baillie, M.G.L., Bard, E., Bayliss, A., Beck, J.W., Blackwell, P.G., Bronk Ramsey, C., Buck, C.E., Burr, G.S., Edwards, R.L., Friedrich, M., Grootes, P.M. Guilderson, T.P., Hajdas, I., Heaton, T.J., Hogg, A.G., Hughen, K.A., Kaiser, K.F., Kromer, B., McCormac, F.G., Manning, S.W., Reimer, R.W., Richards, D.A., Southon, J.R., Talamo, S., Turney, C.S.M., van der Plicht, J., Weyhenmeyer, C.E., 2009. IntCal09 and Marine09 radiocarbon age calibration curves, 0-50,000 years cal BP. Radiocarbon 51 (4), 1111-1150.

Riel-Salvatore, J., 2009. What is a 'transitional' industry? The Uluzzian of southern Italy as a case study. In: Camps, M., Chauhan, P. (Eds.), Sourcebook of Paleolithic Transition. Springer Science, pp. 377-396.

Riel-Salvatore, J., Negrino, F., 2009. Early Upper Paleolithic population dynamics and raw material procurement and patterns in Italy. In: Camps i Calbet, M.,
Szmidt, C. (Eds.), The Mediterranean Between 50-25,000 BP: Turning Points and New Directions. Oxbow, Oxford, pp. 205-224.

Ronchitelli, A., Boscato, P., Gambassini, P., 2009. Gli Ultimi Neandertaliani in Italia: Aspetti culturali. In: Facchini, F., Belcastro, M.G. (Eds.), La Lunga Storia di Neandertal. Biologia e Comportamento. Jaca Book, Milano, pp. 257-287.

Schmitz, R.W., Serre, D., Bonani, G., Feine, S., Hillgruber, F., Krainitzki, H., Pääbo, S., Smith, F.H., 2002. The Neandertal type site revisited: interdisciplinary investigations of skeletal remains from the Neander Valley, Germany. Proceedings of the National Academy of Sciences of the United States of America 99, 13342-13347.

Semal, P., Rougier, H., Crevecoeur, I., Jungles, C., Flas, D., Hauzeur, A., Maureille, B., Germompré, M., Bocherens, H., Pirson, S., Cammaert, L., De Clerck, N., Hambucken, A., Higham, T., Toussaint, Van der Plicht, J., 2009. New data on the late Neanderthals: direct dating of the Belgian spy fossils. American Journal of Physical Anthropology 138, 421-428.

Serre, D., Langaney, A., Chech, M., Teschler-Nicola, M., Paunovic, M., Mennecier, P., Hofreiter, M., Possnert, G., Pääbo, S., 2004. No evidence of Neandertal mtDNA contribution to early modern humans. PLoS Biology 2 (3), E57.

Smith, F., Falsetti, A., Donnelly, S., 1999. Modern human origins. Yearbook of Physical Anthropology 32, 35-68.

Straus, L., 2007. Even the notion of "transitional industry" is a suspect typological construct. In: Riel-Salvatore, J., Clark, J. (Eds.), New Approaches to the Studies of the Early Upper Paleolithic "Transitional" Industries of Western Eurasia. British Archaeological Reports, International Series, vol. 1620, pp. 11-18.

Thun-Hohenstein, U., Parere, V., Sala, B., Giunti, P., Longo, L, 2012. large mammals from Mezzena rockshelter: new biocronological and palaeoecological hypotheses and preliminary data on subsistence strategies. In: Longo, L (Ed.), Middle to Upper Palaeolithic Biological and Cultural Shift in Eurasia. Quaternary International, 259, 1-6.

Wild, E.M., Teschler-Nicola, M., Kutschera, W., Steier, P., Trinkaus, E., Wanek, W., 2005. Direct dating of Early Upper Palaeolithic human remains from Mladeč. Nature 435, 332-335.

Zilhão, J., 2006. Neandertals and moderns mixed, and it matters. Evolutionary Anthropology 15, 183-195. 